\title{
DIKDAS MATAPPA: Jurnal Ilmu Pendidikan Dasar
}

Vol, 3. No, 2. September 2020 p-ISSN: 2620-5246 dan e-ISSN: 2620-6307

Link: http://journal.stkip-andi-matappa.ac.id/index.php/dikdas

(c) (i) This work is licensed under a Creative Commons Attribution

4.0 International License

\section{Pengembangan Media Komik Berbasis Digital Terhadap Kemampuan Berpikir Kritis Siswa Pada Materi Metamorfosis Di Kelas Tinggi}

\author{
Feni Andayani ${ }^{1^{*}}$, Luthfi Hamdani Maula ${ }^{2}$, Astri Sutisnawati ${ }^{3}$ \\ Pendidikan Guru Sekolah Dasar/Universitas Muhammadiyah Sukabumi \\ Email: feni.andayani19@gmail.com \\ Pendidikan Guru Sekolah Dasar/Universitas Muhammadiyah Sukabumi \\ Email: luthfihamdani@gmail.com \\ Pendidikan Guru Sekolah Dasar/Universitas Muhammadiyah Sukabumi \\ Email: astri212@ummi.ac.id
}

\begin{abstract}
This study aims to develop digital-based comic media on students' critical thinking skills on high-class metamorphosis material. This type of research uses Research and Development $(\mathrm{RnD})$. The research instrument used questionnaires and tests. The subject of this research was conducted by a validator (a media expert lecturer, a material expert lecturer and 2 homeroom teachers). It can be concluded that the quality of comic products as a learning medium for critical thinking skills based on validation results by expert lecturers and practitioners. The final result of the comic media feasibility assessment on each component is that the content, material and media feasibility components are categorized as 'Excellent' by experts and practitioners, making it very feasible to test.
\end{abstract}

Keyword: Elemantary School; Online Learning; Understanding Mathematical Concepts.

\begin{abstract}
Abstrak. Penelitian ini bertujuan untuk mengembangkan media komik berbasis digital terhadap kemampuan berpikir kritis siswa pada materi metamorfosis di kelas tinggi. Jenis penelitian ini menggunakan Research and Development (RnD). Instrumen penelitian ini menggunakan angket dan tes. Subjek penelitian ini dilakukan oleh validator (dosen ahli media, dosen ahli materi dan 2 guru wali kelas). Dapat disimpulkan bahwa kualitas produk komik sebagai media pembelajaran untuk kemampuan berpikir kritis berdasarkan hasil validasi oleh dosen ahli materi dan praktisi. Hasil akhir penilaian kelayakan media komik pada setiap komponen yaitu komponen kelayakan isi, materi dan media dikategorikan dengan 'Sangat Baik' oleh ahli dan praktisi, sehingga sangat layak untuk diuji cobakan.
\end{abstract}

Kata Kunci: Keterampilan Berpikir Kritis; Media Komik; Sekolah Dasar.

\section{PENDAHULUAN}

Perkembangan ilmu dan teknologi pada saat ini berkembang begitu pesat, pengetahuan dan keterampilan manusia akan terus menerus berkembang dengan mengikuti zaman. Perkembangan ilmu dan teknologi di abad ke 21 ini menuntut bidang pendidikan agar mempersiapkan peserta didik untuk menghadapi persaingan di era global. Menurut Kemendikbud pada abad 21 peserta didik harus mempunyai 4 kompetensi yaitu "Critical Thinking Problem Solving (berpikir kritis dan menyelesaikan masalah), Creativity (kreativitas), Communication Skills (kemampuan berkomunikasi), and Ability to work Collaboratively (kemampuan untuk bekerjasama)" Kemdikbud, (2017).

Menurut Akbar, dkk. (2017: 17) Pembelajaran tematik pada dasarnya merupakan model dari kurikulum terpadu yang menggunakan tema untuk mengaitkan beberapa mata pelajaran sehingga dapat memberikan pengalaman bermakna kepada peserta didik. Maksud pengalaman bermakna disini mengartikan bahwa pada pembelajaran tematik peserta didik dapat memahami konsep-konsep yang saling berkaitan 
dengan mata pelajaran yang sesuai dengan perkembangan kognitif pada peserta didik. Salah satunya adalah mata pelajaran Ilmu Pengetahuan Alam.

Kurikulum 2013 sudah menetapkan bahwa IPA sebagai mata pelajaran yang terintegrasi untuk mengembangkan keterampilan berpikir, proses dan pengembangan sikap ilmiah. Menurut Sumianto dalam Wedyawati \& Lisa, (2019) terdapat tiga fokus utama pembelajaran IPA di Sekolah Dasar yaitu : (1) IPA Sebagai Produk (2) IPA sebagai Proses (3) IPA sebagai Sikap. Pembelajaran IPA di Sekolah Dasar (SD) atau di Madrasah Ibtidaiyah (MI) memberikan kesempatan kepada siswa untuk mengembangkan rasa ingin tahu secara alamiah sehingga kemampuan bertanya dan mencari jawaban atas berdasarkan bukti serta mengembangkan cara berpikir mereka dalam suatu permasalahan.

Kemampuan berpikir kritis tidak langsung tercipta sejak manusia lahir namun adanya kemampuan berpikir kritis melalui latihan sehingga sudah kewajiban guru harus melatih kemampuan berpikir kritis pada siswa, maka dari itu perlunya rancangan kegiatan IPA yang menarik minat siswa. Salah satunya dengan menggunakan media pembelajaran yang menarik dan dapat membantu guru maupun siswa dalam mempermudah proses pembelajaran.

Menurut Arsyad (2017: 84) Media berbasis visual dapat mempermudah pemahaman dan memperkuat ingat melalui hubungan isi materi melalui gambar yang dibuat seperti nyata. Salah satu media berbasis visual yaitu komik. Komik merupakan komunikasi visual yang mempunyai kekuatan untuk menyampaikan informasi melalui gambar berwana bukan hanya di gemari oleh anak anak saja akan tetapi orang dewasa juga karena ketertarikan sebuah teks yang dipadu dengan sebuah gambar berwarna membuat menarik, dan tidak membosankan sehingga anak dapat memahami teks bacaan lebih mudah.

Sesuai dengan penelitian Arroio (2011) (dalam Jurnal F. Fatimah \& A. Widiyatmoko, 2014:152) yang menyatakan bahwa "media science comic dapat menjadi alat untuk menyampaikan pelajaran IPA kepada siswa dengan cara yang menyenangkan". Arroio menekankan bahwa dengan menggunakan media komik, siswa dapat dengan mudah belajar dan mengingat materi IPA dan membantu terhadap kemampuan berpikir kritis pada siswa. Jadi, media komik berbasis dapat membantu meningkatkan hasil belajar siswa pada materi metamorfosis.

Berdasarkan hal diatas, maka perlu dilakukan penelitian dan pengembangan tentang "Pengembangan media komik berbasis digital terhadap kemampuan berpikir kritis siswa pada materi metamorfosis di kelas tinggi". Hal ini untuk memaparkan prosedur pengembangan media komik pembelajaran IPA dan untuk menghasilkan suatu produk yang layak dari segi valid, praktis dan efektif.

"IPA merupakan ilmu yang mempelajari fenomena alam yang bersifat faktual dan meliputi empat unsur utama yaitu proses, produk, sikap, dan aplikasi". Sari (2019: 53). Proses adalah suatu prosedur pemecahan masalah melalu metode ilmiah. Produk meliputi fakta, teori, prinsip, dan hukum yang dapat digunakan untuk memprediksi suatu gejala alam. Sikap adalah suatu rasa ingin tahu mengenai fenomana alam, makhluk hidup, benda serta hubungan sebab akibat yang melalui sikap ilmiah. Aplikasi adalah suatu penerapan metode ilmiah dan konsep IPA pada kehidupan sehari-hari.

IPA memiliki karakteristik sebagai dasar untuk memahamimya, karakteristik menurut Jacobson \& Bergman (dalam Susanto, 2013: 170), meliputi:

1) IPA merupakan kumpulan konsep, prinsip, hukum, dan teori.

2) Proses ilmiah dapat berupa fisik dan mental, serta mencermati fenomena alam, termasuk juga penerapannya.

3) Sikap keteguhan hati, keingintahuan, dan ketekunan dalam menyingkap rahasia alam.

4) IPA tidak dapat membuktikan semua akan tetapi hanya sebagian atau beberapa saja.

5) Keberanian IPA bersifat subjektif dan bukan kebenaran yang bersifat objektif.

Dewi, dkk. (2013) menyatakan bahwa "Tujuan pembelajaran IPA di SD tidak menjadikan peserta didik sebagai ahli bidang IPA, tetapi dimaksudkan agar peserta didik menajadi orang yang melek ilmu atau literasi sains".

Kuswana (2013: 1) mengarti kata dasar Berpikir ialah "pikir" dalam Kamu Besar Bahasa Indonesia adalah akal budi, ingatan, angan-angan. Artinya 
berpikir merupakan suatu proses yang menggunakan akal dalam mempertimbangkan dan memutuskan suatu masalah. "Berpikir kritis menekankan pada pemikiran yang rasional dan reflektif sehingga dapat mencapai proses pengambilan keputusan.” (Suhartini \& Martyani, 2017: 107). Ini berarti ketika memecahkan sebuah masalah perlunya melakukan pertimbangan secara terus menurus menggunakan akal nya, sehingga dapat mengambil keputusan dengan tepat dan beralasan.

Menurut Richard Paul dan Linda Elder dalam Kasdin Sihotang (2019: 55) menyatakan bahwa setiap orang yang berpikir selalu memuat elmenelmen berikut ini : (1) Tujuan, (2) Sudut Pandang, (3) Konsep, (4) Informasi, (5) Penyimpulan, (6) pertanyaan, (7) Asumsi, (8) Implikasi. Berdasarkan kedelapan elmen diatas menyatakan bahwa setiap orang pasti memiliki kemampuan dalam berpikir kritis dengan melalui tingkatan yang berbeda, tetapi tidak semua orang bisa memfungsikan kemampuan itu secara maksimal, karena setiap orang memiliki kualitas berpikir yang berbeda. Karakter berpikir kritis merupakan hasil pembiasaan dan usaha terus-menurus dengan cara perlunya latihan dan pembiasaan.

Ennis dalam Susanto (2013: 125) terdapat indikator kemampuan berpikir kritis yaitu (1) Memberikan penjelasan sederhana (Elementary Clarification), (2) Membangun kemampuan dasar (Basic Support), (3) Menyimpulkan (Inference), (4) Memberikan penjelasan lebih lanjut (Advanced Clarification), (5) Mengatur strategi dan taktik (Strategy and tactic).

Komik pertama hadir di indonesia sejak tahun 1931, di sebuah majalah Sin Po. Judul komik tersebut ialah "Put On" karya Kho Wang Gie. Kemudian disusul pada tahun 1939 karya Nasroen A yang berjudul "Mencari Putri Hijau". Komik indonesia mengalami kemanjuan dan disukai oleh banyak orang pada dekade 1960 sampai 1970. Di era itu banyak komikus berbakat dan menciptakan karya yang melegenda seperti Si Buta dari Gua Hantu (Ganes TH), Mahabhrata (R.A. Kosasih) dan masih banyak lagi, sedangkan pada tahun 1980an komik indonesia memasuki masa yang kurang diminati namun pasca reformasi dunia komik indoneisa berusaha bangkit. Seiringnya zaman dan teknologi kini kehadiran komik tidak hanya dalam bentuk cetak akan tetapi berkembang lewat media atau komik digital.
Media dua dimensi dalam bentuk visual atau grafis yaitu komik. Menurut Burhan Nurgiyantoro (2018: 409) menyatakan bahwa "Komik pada mulanya berkaitan dengan segala sesuatu yang lucu, komik dalam bahasa belanda dari kata "Komiek" yang berarti 'pelawak'. Atau dari bahasa yunani kuno, istilah komik berasal dari kata "komikos", yang merupakan kata bentuk dari "kosmos" yang berarti 'bersuka ria' atau 'bercanda'. Hal ini menyatakan bahwa komik sering dikaitkan dengan hal-hal yang lucu seperti dari gambar nya yang tidak proposional tapi memiliki makna yang dalam.

Arsyad (2017: 3). Menurut Dermawan dalam Zuhrowati, dkk. (2018: 145) menyatakan bahwa "Komik dapat didefinisikan sebagai sebuah cerita atau pengungkapan ide yang dituangkan dalam bentuk gambar". Dalam artian komik merupakan bentuk komunikasi visual yang memiliki kekuatan untuk menyampaikan informasi, ide yang dituangkan dalam bentuk gambar membuat ceritanya menjadi mudah diserap oleh siswa. Sedangkan Menurut Arrio dalam Lestri (2016: 566) "Komik dapat berperan sebagai media yang berfungsi sebagai penyampaian pesan atau informasi ilmiah dengan cara visual yang menghibur".

Berdasarkan penjelasan di atas dapat disimpulkan bahwa komik merupakan perpaduan antara gambar dan teks yang memiliki kekuatan untuk menyampaikan isi materi agar mudah dimengerti dan mudah di serap oleh siswa. Konsep-konsep yang berubah abstrak dapat dituangkan dalam media visual bergambar menjadi konsep yang konkret dapat mudah dipahami oleh siswa.

Komik digital adalah komik yang berbentuk format digital berbasis elektronik yang tidak hanya menampilkan alur cerita saja, namun didalamnya dapat disisipkan seperti game, animasi, film atau aplikasi lainnya yang dapat mempermudah pembaca dalam mengikuti dan menikmati alur cerita. (Mawadah, 2016 :31).

Secara sederhana, komik digital dibagi menjadi empat kategori berdasarkan aplikasi digitalnya yaitu :

1) Digital Production, mengacu pada proses berkarya dan produksi komik kini bisa dilakukan $100 \%$ on screen, dan tidak sekedar proses menipulasi dan olahan digital semata. 
2) Digital Form, mengacu pada bentuk komik yang berbentuk digital, sehingga kini memiliki kemampuan yang tidak seperti kertas yang dibatasi ukuran format, sehingga bisa memiliki bentuk yang tidak terbatas.

3) Digital Delivery, mengacu pada metode penghantaran komik secara digital yang dalam bentuk paperless dan high mobility.

4) Digital Convergence

Digital Convergence adalah pengembangan komik dalam tautan media lainnya yang juga berbasis digital, misalnya sebagai game, animasi, film, mobile content, dan sebagainya.

Menurut Maharsi (2014: 7) Komik memiliki banyak elemen pembentukannya, elemen ini merupakan ciri khas dari komik dibandingkan dengan media yang lain. Ciri ciri khas sebagai berikut (1) Panel (2) Parit, (3) Balon kata, (4) Ilustrasi (5) Cerita.

Teknik cara menggambar terdapat 3 cara yaitu teknik digital, manual, dan hybrid.dalam Maharsi (2014: 16) yaitu (1) Teknik Digital, (2) Teknik manual, (3) Teknik hybrid. Berdasarkan teknik pembuatan media komik dalam pengembangan ini peneliti menggunakan teknik hybrid yaitu penggabungan dari teknik digital yang menggunakan sofware yaitu adobe photoshop yang digunakan untuk membantu dalam perhalusan gambar. dan teknik manual yang dilakukan sebelum menggunakan sofware.

Menurut Trimo dalam Laksana (2015: 157) ada empat kelebihan dari media komik, yaitu (1) Komik menambah pembendaharaan kata-kata pembacanya, (2) Mempermudah anak didik menangkap hal-hal atau rumusan yang abstrak, (3) Dapat mengembangkan minat baca anak dan salah satu bidang studi yang lainya, (4) Seluruh jalan cerita komik pada menuju satu hal yakni. Menurut Trimo dalam Pebriansyah (2015: 67) ada tiga kekurangan dari media komik yaitu (1) Membuat malas membaca sehingga menyebabkan penolakan-penolakan pada bukubuku yang tidak bergambar, (2) Dari segi Bahasa komik hanya menggunakan kata-kata atau kalimat-kalimat yang kurang dapat dipertanggung jawabkan.

\section{METODE PENELITIAN}

Jenis penelitian dalam penelitian ini menggunakan metode Research \& Development
(R\&D). Model penelitian pengembangan yang digunakan dalam penelitian ini adalah model prosedural, yaitu model yang menggambarkan alur atau langkah-langkah. Berdasarkan Sugiyono yang diadaptasi dari Borg and Gall (2012:409) langkah-langkah penelitian yang harus diikuti untuk menghasilkan suatu produk terdapat 10 langkah yaitu, Potensi dan masalah, pengumpulan data, desain produk, validasi desain, revisi desian, ujicoba produk, revisi produk, ujicoba pemakaian, revisi produk, produksi masal.

Penelitian pengembangan media komik ini mengacu pada prosedur yang dikemukakan oleh Sugiyono (2015:409) diadaptasi sesuai dengan prosedur pengembangan bahan intruksional oleh Borg and Gall. Prosedur ini dipilih karena langkah-langkahnya sederhana namun terperinci. Prosedur ini terdapat 10 langkah. Langkahlangkah penelitian pengembangan dapat dilihat pada gambar 3.1

Gambar 3.1 Langkah-langkah penggunaan metode $\mathrm{R} \& \mathrm{D}$ yang diadaptasi dari Borg and Gall (Sugiyono, 2015:409)

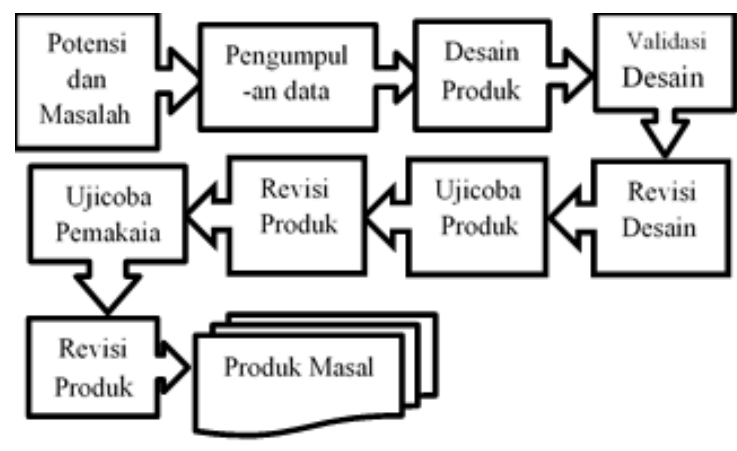

(1)Potensi dan masalah, (2) Pengumpulan data, (3) Desain produk, (4) Validasi desain, (5) Revisi desain, (6) Uji coba produk, (7) Revisi produk, (8) Uji coba pemakaian, (9) Revisi produk, (10) Produk masal.

Model ini memiliki langkah-langkah yang sesuai dengan penelitian pengembangan dalam pendidikan yaitu menghasilkan atau mengembangkan sebuah produk dengan melakukan sebuah uji kepada ahli sepeti uji kepada ahli media, uji kepada ahli materi, uji kepada guru/praktisi dan uji lapangan, hal ini untuk mengetahui kebermanfaatan dan keefektifan produk tersebut. 
Dalam penelitian ini dilakukan langkah-langkah penelitian pengembangan hanya sampai ke-7 tidak sampai produksi masal dikarenakan kondisi pandemi saat ini dan keterbatasan waktu yang dibutuhkan untuk membuat pengembangan media sampai produksi masal membutuhkan waktu yang cukup lama. Pengembangan produk media komik ini tidak untuk diperjual belikan hanya untuk mengetahui kelayakan media komik sebagai bahan ajar sehingga peneliti menggunakan tujuh langkah metode pengembangan Research \& Development (R\&D) yang telah diuji dan divalidasi oleh ahli media, materi dan guru/praktisi.

Gambar 3.2 Tujuh langkah-langkah penggunaan metode R\&D yang diadaptasi dari Borg and Gall (Sugiyono, 2015:409)

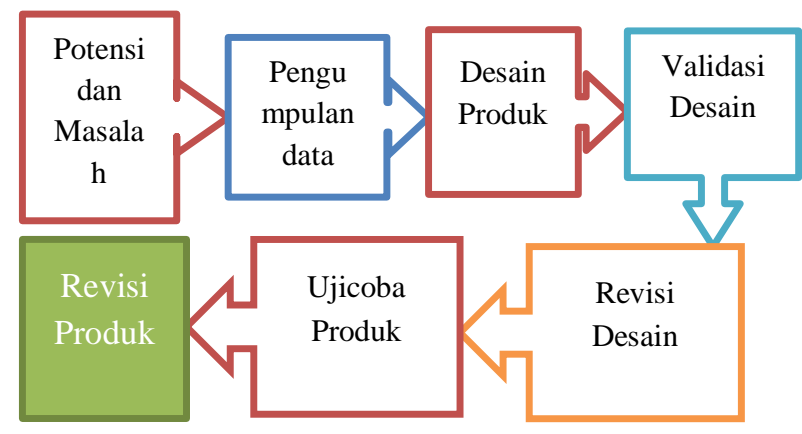

Tujuh Langkah-langkah yang dilakukan dalam penelitian pengembangan meliputi (1) Potensi dan masalah. Pada kegiatan awal penelitian sebelum melakukan pengembangan media komik yaitu berupa wawancara dalam kegiatan pembelajaran di SDN 1 Cisande . (2) Pengumpulan data. Setelah mendapatkan data potensi dan masalah perlu dikumpulkan berbagai informasi mengenai pengembangan media pembelajaran berupa komik berbasis digital khususnya pembelajaran IPA materi metamorfosis yang dapat digunakan sebagai bahan perencanaan produk yang diharapkan untuk mengatasi masalah tersebut. (3) Desain produk. Perencanaan pembuatan desain produk awal adalah mengumpulkan bahan bahan untuk dijadikan referensi dalam penyusunan dan pembuatan media komik berbasis digital, (4) Validasi desain Proses untuk menilai rancangan produk apakah produk yang dibuat akan lebih efektif dari yang lama atau tidak dan juga untuk mengetahui kelemahan dan keunggulan produk tersebut. (5) Revisi desain Setelah validasi desain yang dilakukan oleh beberapa ahli, produk tersebut dapat diketahui kelemahannya, hal ini peneliti dapat memperbaiki desain nya agar lebih baik, (6) Uji coba produk dibuat tidak langsung diuji coba dulu, tetapi harus sudah menjadi sebuah barang dan barang itulah yang akan diuji coba, (7) Revisi produk Hasi uji coba produk tersebut, apabila tanggapan pendidik ataupun peserta didik mengatakan bahwa produk ini baik dan menarik untuk dibaca.

a. Desain ujicoba produk dilakukan melalui 2 tahap pelaksanaan yaitu (1) Tahap ini dilakukan oleh dosen pembimbing, dosen ahli media dan ahli materi, dan guru kelas 4 dan 1 , (2) Tahap ini jika sudah direvisi selajutnya uji lapangan yaitu komik digunakan dalam pembelajaran. Hal ini dapat mengetahui peningkatan kemampuan berpikir kritis siswa melalui pretest-posttest setelah pembelajaran menggunakan komik.

b. Ujicoba produk dilakukan dengan rancangan desain eksperimen untuk membandingkan keadaan sebelum dan sesudah menggunakan media komik (Before-after). Dalam hal ini ada kelompok eksperimen dan kelompok kontrol.

Subjek dalam penelitian ini dilakukan Juni 2020 di SDN 1 Cisande, Kecamatan Cicantayan, Kabupaten Sukabumi pada tahun ajaran 2019/2020. Peneliti mengumpulkan data meggunakan cara seabagai berikut (1) Angket, (2) Tes (3) Respon siswa. Peneliti menggunakan teknik analisis data dalam melakukan penelitian melalui angket dan tes. Data yang dianalisis meliputi (1) Analisis kelayakan media komik, (2) Analisis statistik hasil belajar siswa melalui tes.

\section{HASIL DAN PEMBAHASAN}

\section{Hasil}

Hasil penelitian pengembangan pada media komik berbasis digital sebagai media pembelajaran pada pembelajaran Ilmu Pengetahuan Alam (IPA) yang diuraikan berdasarkan langkah Borg and Gall yang diadaptasi oleh Sugiyono yaitu :

1) Potensi dan Masalah

Potensi dalam penelitian ini yaitu terdapat pada komik berbasis digital yang berfungsi sebagai media pembelajaran untuk kemampuan berpikir kritis siswa kelas IV SD pada pelajaran IPA. Masalah dari penelitian 
ini yaitu belum adanya media pembelajaran yang menarik perhatian siswa.

2) Pengumpulan Data

Pengumpulan data dalam penelitian ini berupa penelitian yang menunjang terkait media pembelajaran cara pembuatan komik.

3) Desain Produk

Pada tahapan desain produk peneliti melakukan proses penggambaran pada buku tulis sebagai coretan, setelah itu dilakukan pada buku sketsa (Sketsh Book) berukuran A4.

4) Validasi Desain,

Sebelum media komik diuji cobakan di lapangan, produk akan divaliditas terlebih dahulu dengan 4 ahli yaitu ahli materi, ahli media dan 2 respon pendidik. Adapun hasil dari ahli media, ahli materi dan respon pendidik, yaitu sebagai berikut:

(a) Validasi Ahli (Media dan Ahli Materi) Validasi ahli media dan ahli materi ini bertujuan untuk menguji penyajian media komik. Data hasil validasi dari ahli materi meliputi kelayakan isi pada tabel 4.1 sedangkan validasi dari ahli media meliputi bahasa dan media pada tabel 4.2 berikut tabelnya:

Tabel 4.1. Data Hasil Penelitian oleh Ahli Materi

\begin{tabular}{ccccc}
\hline No. & Komponen & $\begin{array}{c}\text { Rerata } \\
\text { Skor }\end{array}$ & $\begin{array}{c}\text { Jumlah } \\
\text { Skor }\end{array}$ & Kategori \\
\hline 1. & $\begin{array}{c}\text { Kelayakan } \\
\text { Isi }\end{array}$ & 4,5 & 45 & $\mathrm{~A}$ \\
& & & & \\
\hline
\end{tabular}

Tabel 4.2. Data Hasil Penelitian oleh Ahli Media

\begin{tabular}{llrrc}
\hline No. & Komponen & Rerata & $\begin{array}{l}\text { Jumlah } \\
\text { Skor }\end{array}$ & Kategori \\
\hline 1. & Bahasa & 3,6 & 54 & B \\
\hline 2. & Media & 3,92 & 51 & B
\end{tabular}

Berdasarkan dari hasil penilaian komponen kelayakan isi oleh ahli materi yaitu dengan jumlah skor 45 dan rerata skor 4,5 hasil menunjukan bahwa dari segi kelayakan dalam kategori A. Sedangkan hasil data oleh ahli media pada komponen bahasa memperoleh rerata skor 3,6 dan jumlah skor 54 dengan kategori $\mathrm{B}$, dan komponen media memperoleh rerata skor 3,92 dan jumlah skor 51 dengan kategori B. (b) Validasi oleh Praktisi

Validasi dari praktisi yang dilakukan oleh guru kelas 4 dan guru kelas 1. Data hasil validasi dari praktisi meliputi kelayakan isi, bahasa dan media, pada tabel 4.3:

Tabel 4.3 Data Hasil Validasi Media oleh Praktisi

\begin{tabular}{llccc}
\hline No. & Komponen & Rerata & $\begin{array}{c}\text { Jumlah } \\
\text { Skor }\end{array}$ & Kategori \\
\hline 1. & $\begin{array}{l}\text { Kelayakan } \\
\text { Isi }\end{array}$ & 5 & 50 & $\mathrm{~A}$ \\
\hline 2. & Bahasa & 4,86 & 73 & $\mathrm{~A}$ \\
\hline 3. & Media & 4,86 & 63,5 & $\mathrm{~A}$ \\
\hline
\end{tabular}

Berdasarkan dari hasil validasi isi oleh praktisi, setiap komponen mendapat kategori layak, dari komponen kelayakan isi dengan jumlah skor 50 dan rerata skor 5 , kemudian komponen bahasa dengan jumlah skor 73 dan rerata skor 4,86. Dan komponen media dengan jumlah skor 63,5 dan rerata skor 4,86. Hal ini dilakukan oleh 2 validator.

Data keseluruhan hasil validasi media komik dapat diperoleh dari hasil jumlah rerata skor ahli materi, ahli media dan guru pada tiap komponen pada tabel 4.4:

Tabel 4.4 Data Hasil Validasi Secara Keseluruhan Media oleh Validator

\begin{tabular}{llccc}
\hline \multirow{2}{*}{ No. } & Komponen & \multicolumn{2}{c}{ Skor dari } \\
& & $\begin{array}{c}\text { Validator } \\
\text { Dosen } \\
\text { Ahli }\end{array}$ & Praktisi & $\begin{array}{c}\text { Rerata } \\
\text { Skor }\end{array}$ \\
\hline 1. & Kelayakan Isi & 45 & 50 & 47,5 \\
\hline 2. & Bahasa & 54 & 73 & 63,5 \\
\hline 3. & Media & 51 & 63,5 & 57,25 \\
\hline
\end{tabular}

Hasil konversi skor menjadi skala lima secara umum dapat dilihat pada tabel 4.5

Tabel 4.5 Konversi Skor Menjadi Skala Lima

\begin{tabular}{llccc}
\hline $\begin{array}{c}\text { Kompene } \\
\text { n } \\
\text { Penilaian }\end{array}$ & $\begin{array}{c}\text { Rentang } \\
\text { Skor }\end{array}$ & $\begin{array}{c}\text { Nil } \\
\text { ai }\end{array}$ & $\begin{array}{c}\text { Kate } \\
\text { gori }\end{array}$ & $\begin{array}{c}\text { Keter } \\
\text { angan }\end{array}$ \\
\hline $\begin{array}{l}\text { Kelayaka } \\
\text { n Isi }\end{array}$ & $\mathrm{X}>42,94$ & A & $\begin{array}{c}\text { Sanga } \\
\text { t Baik }\end{array}$ & $\begin{array}{c}\text { Dosen } \\
\text { Ahli } \\
\text { Praktis } \\
\text { i }\end{array}$ \\
& & & & \\
\cline { 2 - 5 } & $35,98<\mathrm{X}$ & B & Baik & \\
\hline 442,94 & & & \\
\hline
\end{tabular}




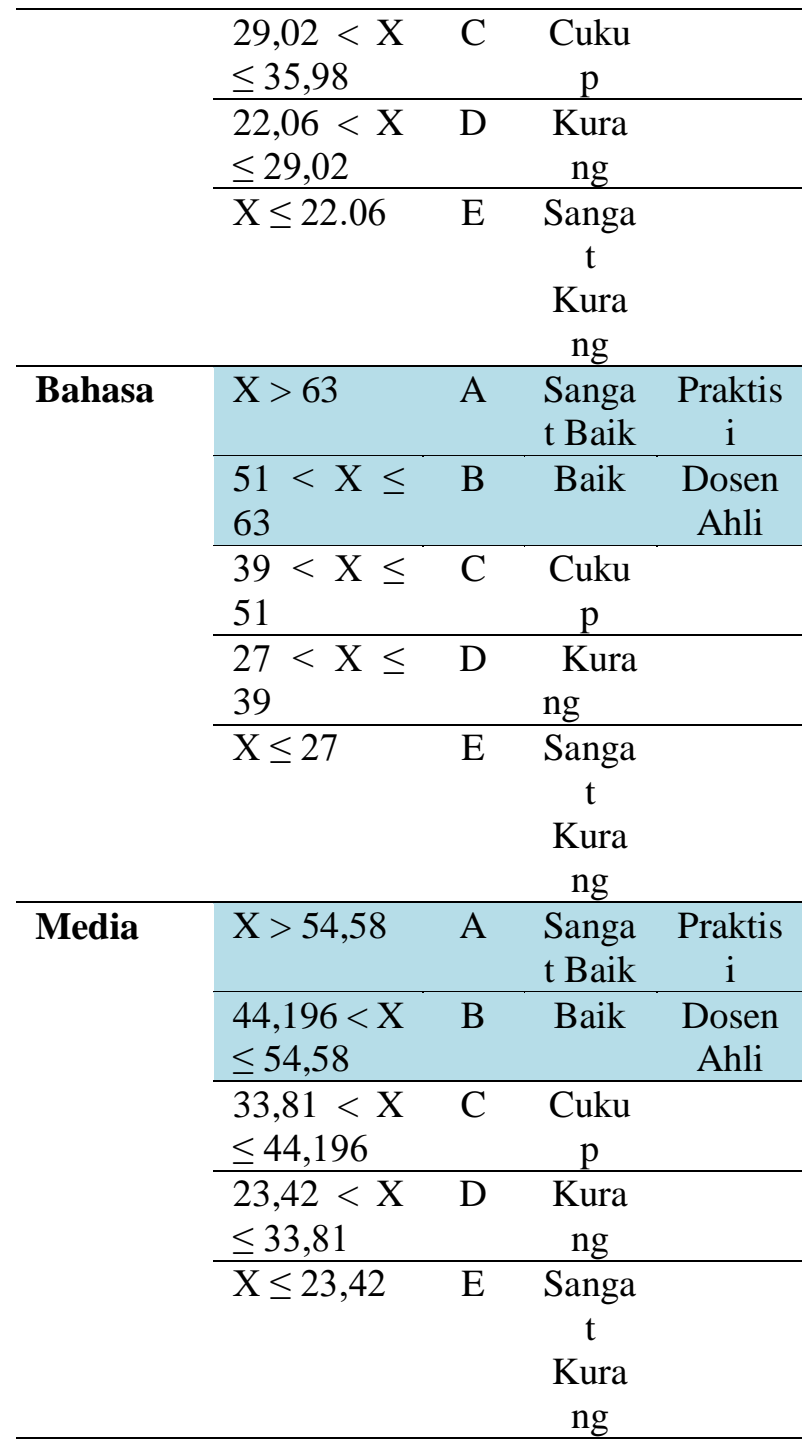

Maka hasil akhir yang diperoleh pada setiap komponennya disajikan pada (Tabel 4.6).

Tabel. 4.6 Hasil Akhir Penilaian Kelayakan Media Komik pada Setiap Komponen

\begin{tabular}{llccl}
\hline No. & Komponen & $\begin{array}{c}\text { Jumlah } \\
\text { Skor }\end{array}$ & Nilai & Kategori \\
\hline 1. & $\begin{array}{l}\text { Kelayakan } \\
\text { Isi }\end{array}$ & 47,5 & A & $\begin{array}{l}\text { Sangat } \\
\text { Baik }\end{array}$ \\
\hline 2. & Bahasa & 63,5 & A & $\begin{array}{l}\text { Sangat } \\
\text { Baik }\end{array}$ \\
\hline 3. & Media & 57,25 & A & $\begin{array}{l}\text { Sangat } \\
\text { Baik }\end{array}$ \\
\hline
\end{tabular}

5) Revisi Desain

Peneliti melakukan revisi desain terhadap desain produk yang akan dikembangkan berdasarkan saran dan masukan dari ahli dan praktisi. Adapun saran masukan untuk perbaikan produk komi, yaitu sebagai berikut :

(a) Revisi Desain dari Ahli Materi

Revisi desain dari ahli materi terdapat pada komponen kelayakan ini dengan saran untuk perbaikan yaitu menambahkan penjelasan pengertian metamorfosis, jenis metamorfosis, tabel perbandingan siklus kecoa dan kupu-kupu dan juga tambahkan latihan kemampuan berpikir kritis.

(b) Revisi Desain dari Ahli Media

Revisi desain dari ahli media terdapat pada komponen desain sampul dengan saran yaitu cover sampul dibuat lebih menarik dengan ditambahkan sosok mimi dan kakanya sedang berinteraksi dengan kupu-kupu atau kecoa, lalu buat profile tentang mimi dan kakanya agar siswa juga dapat mengenal dahulu karakter tokohnya.

6) Uji Coba Produk

Setelah produk komik telah divalidasi oleh dosen ahli dan telah selesai diperbaiki, selanjutnya produk akan diuji cobakan untuk mengetahui kemampuan kritis siswa kelas 4 SD. data hasil uji coba produk berupa angket sesudah menggunakan angket dapat dilihat dari tabel 4.7 dan data hasil uji coba produk berupa tes dapat dilihat dari tabel 4.8:

Tabel. 4.7 Data Hasil Respon Siswa melalui Angket

\begin{tabular}{lllll}
\hline No. & Aspek & $\begin{array}{l}\text { Jumlah } \\
\text { Skor }\end{array}$ & $\begin{array}{l}\text { Rerata } \\
\text { Skor }\end{array}$ & Kategori \\
\hline 1. & $\begin{array}{l}\text { Kelayak } \\
\text { an Isi }\end{array}$ & 238 & 47,6 & $\begin{array}{l}\text { Sangat } \\
\text { Baik }\end{array}$ \\
\hline 2. & Bahasa & 235 & 47 & $\begin{array}{l}\text { Sangat } \\
\text { Baik }\end{array}$ \\
\hline 3. & Media & 244 & 48,8 & $\begin{array}{l}\text { Sangat } \\
\text { Baik }\end{array}$ \\
\hline
\end{tabular}

Tabel 4.8 Data Hasil Kemampuan Berpikir Kritis melalui Tes

\begin{tabular}{lllll}
\hline No. & Keterangan & \multicolumn{2}{c}{$\begin{array}{c}\text { Skor yang } \\
\text { diperoleh siswa }\end{array}$} & $\begin{array}{c}\text { Gain } \\
\text { Score }\end{array}$ \\
\cline { 3 - 4 } & & Pretest & Postets & \\
\hline 1 & Jumlah & 660 & 802 & $\mathbf{0 , 4 1}$ \\
\hline 2 & Rerata & 66 & 80,2 & \\
\hline
\end{tabular}

Kriteria peningkatan dalam kategori Sedang

Kemampuan berpikir kritis siswa diukur dengan menggunakan instrumen soal essay yang telah disusun berdasarkan indikator kemampuan 
berpikir kritis yang diadaptasi dari Ennis dalam Susanto (2013: 125) Terdapat 5 indikator kemampuan berpikir kritis yaitu memberi penjelasan sederhana, membangun kemampuan dasar, menyimpulkan, membuat penjelasan lebih lanjut, dan membuat strategi. Kelima indikator ini kemudian dijabarkan dalam sub indikator kemampuan berpikir kritis.

Berdasarkan data hasil kemampuan berpikir kritis melalui tes mendapatkan jumlah 660 untuk pretest dan 802 untuk posttest, dengan rerata pretest 66 dan rerata posttest 80,2 . Jadi, gain score yang diperoleh adalah 0,41 berkategori sedang karena $0,30 \leq(0,41)<0,70$.

\section{Pembahasan}

1. Kelayakan media komik

a. Kelayakan Isi

Pengembangan pada produk yang dihasilkan oleh peneliti adalah media komik berbasis digital yang telah melewati serangkaian uji untuk mendapatkan saran dan masukan sehingga komik ini layak digunakan dalam pembelajaran yang terdiri dari validasi media dan materi melibatkan dosen ahli, kemudian validasi melibatkan guru kelas 4 dan kelas 1 dan juga uji lapangan yang melibatkan siswa. Dalam kelayakan isi ini terdapat 10 pernyataan untuk di isi kepada ahli materi dan praktisi.

Data hasil pada komponen kelayakan isi yang divalidasi oleh ahli materi jumlah skor yang diperoleh 45 dengan kriteria sangat baik (SB), sedangkan komponen kelayakan isi yang divalidasi oleh guru jumlah skor yang diperoleh 50 dengan kriteria sangat baik (SB). Secara keseluruhan, pada komponen kelayakan isi memperoleh nilai rata-rata jumlah yaitu 47,5 dengan kriteria sangat baik(SB)

Gambar. 4.8 Diagram Kelayakan Isi oleh Ahli dan Praktisi

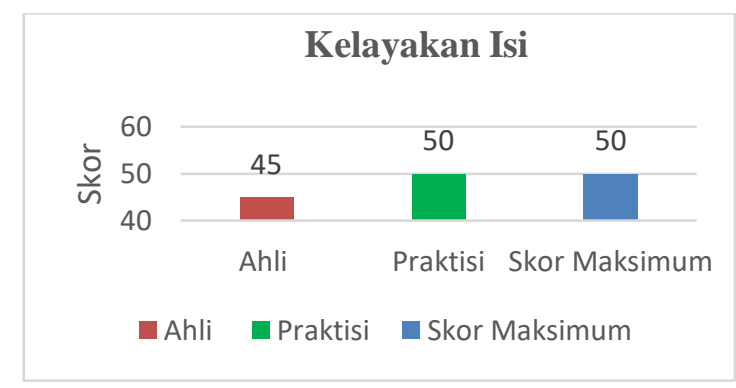

b. Bahasa

Data hasil pada komponen bahasa yang divalidasi oleh ahli media komik berbasis digital mendapatkan jumlah skor yang diperoleh 54 dengan kriteria baik (B), sedangkan komponen bahasa yang divalidasi oleh guru jumlah skor yang diperoleh 73 dengan kriteria sangat baik (SB). Adapun aspek bahasa untuk media komik yang dikembangkan antara lain, penggunaan kalimat, penggunaan ejaan, dan penggunaan penulisan. Komponen bahasa memiliki 15 pernyataan.

Gambar. 4.9 Diagram Bahasa oleh Ahli dan Praktisi

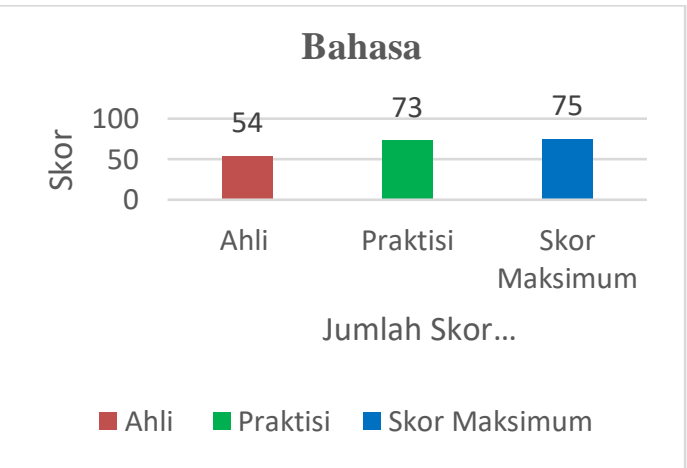

\section{c. Media}

Data hasil pada komponen media yang divalidasi oleh ahli media jumlah skor yang diperoleh 51 dengan kriteria baik (B), sedangkan komponen bahasa yang divalidasi oleh guru jumlah skor yang diperoleh 63,5 dengan kriteria sangat baik (SB). Adapun aspek media untuk media komik yang dikembangkan antara lain, desain sampul dan penggunaan gambar.

Gambar. 4.10 Diagram Media oleh Ahli dan Praktisi

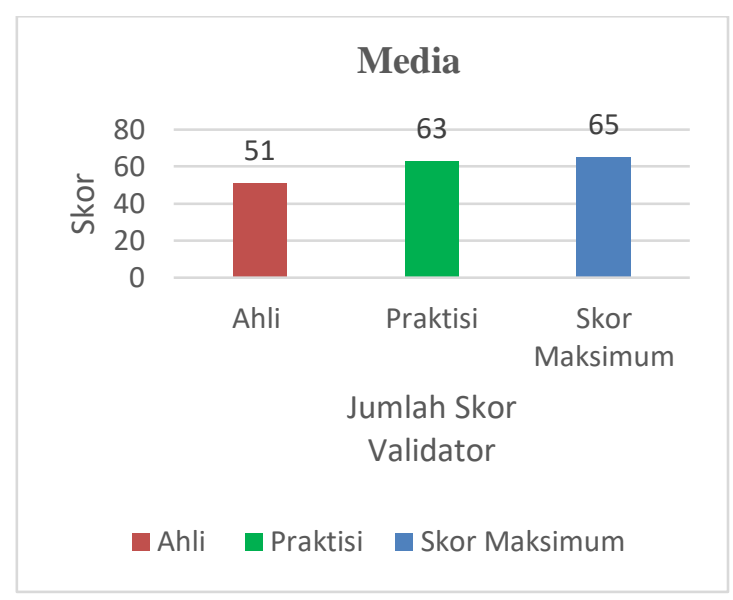


2. Hasil Belajar dan Respon Siswa

a. Hasil Belajar

Hasil belajar siswa untuk mengetahui sejauh mana kemampuan berpikir kritis terhadap materi pembelajaran dengan melakukannya tes. Dalam penelitian ini peneliti menggunakan instrumen soal tes essay yang mengacu pada taksonomi bloom (antarai $\mathrm{C}_{1}-\mathrm{C}_{6}$ ) dengan jumlah 10 soal.

Hasil belajar siswa dari sebelum menggunakan media komik berbasis digital sampai setelah penggunaan media komik berbasis digital menunjukkan adanya peningkatan. Kemampuan media komik dalam menyajikan materi metamorfosis. Dapat tersampaikan dengan baik kepada siswa melalui media komik berbasis digital. Bahasa yang sederhana, tampilan yang menarik membuat siswa memahami materi dengan lebih mudah. Kelebihan dari media komik berbasis digital tersebut menjadi salah satu faktor dalam memudahkan pemahaman siswa sehingga hasil belajar siswa meningkat. Berdasarkan hasil perhitungan dan analisis data, terdapat peningkatan secara keseluruhan rata rata skor pretetes yang diperoleh siswa yaitu 66 dan rata rata skor posttest 80,2. Peningkatan hasil belajar dari rata-rata skor pretest dan posttets dengan menggunakan rumus gain score yang diperoleh sebesar 0,41 dengan kriteria sedang.

Gambar. 4.11 Diagram Peningkatan Hasil Belajar

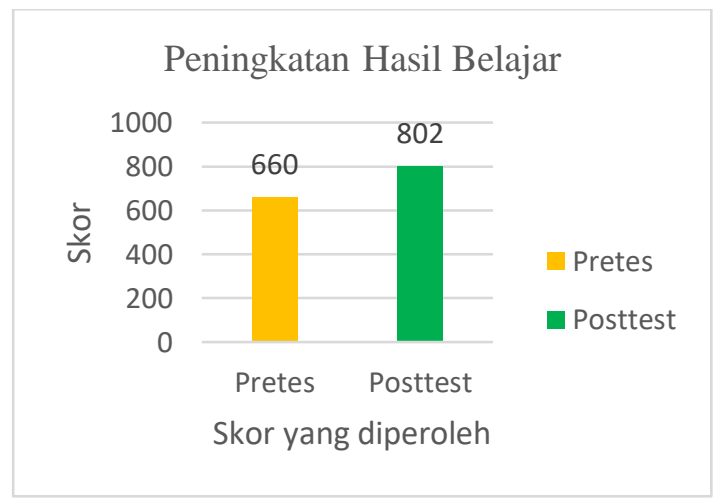

Sesuai dengan penelitian Arroio (2011) (dalam F. Fatimah \& A. Widiyatmoko, 2014:152) yang menyatakan bahwa "media science comic dapat menjadi alat untuk menyampaikan pelajaran IPA kepada siswa dengan cara yang menyenangkan". Arroio menekankan bahwa dengan menggunakan media komik, siswa dapat dengan mudah belajar dan mengingat materi IPA dan membantu terhadap kemampuan berpikir kritis pada siswa.
Jadi, media komik berbasis dapat membantu meningkatkan hasil belajar siswa pada materi metamorfosis.

\section{b. Respon Siswa}

Media yang dikembangkan dapat dikatakan layak digunakan apabila telah diuji cobakan kepada siswa. Setelah melakukannya posttets, peneliti meminta siswa untuk mengisi angket kelayakan media komik kepada siswa. Agar dapat mengetahui kualitas tiap komponenenya, peneliti menggunakan skala likert, Skala ini digunakan untuk mengukur sikap individual. Jawaban setiap item mempunyai gradasi dari sangat positif sampai sangat negatif hasil dapat dilihat pada gambar 4.12 dan 4.13:

Gambar 4.12 Diagram Persentase Respon Siswa

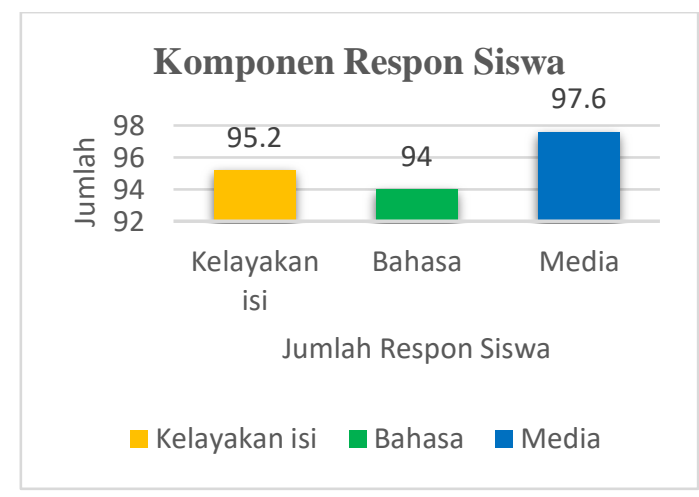

Gambar 4.13 Kriteria Interpretasi Skor

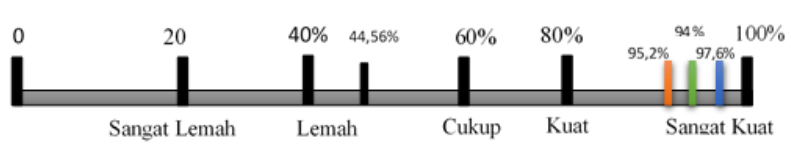

Berdasarkan hasil respon siswa diatas, terdapat tiga komponen yaitu komponen kelayakan isi jumlah skor yang diperoleh 95,2\% dengan kriteria sangat kuat, kemudian komponen bahasa jumlah skor yang diperoleh $94 \%$ dengan kriteria sangat kuat dan komponen media jumlah skor yang diperoleh 97,6 dengan kriteria sangat kuat dapat dilihat pada gambar. 4.12. jadi dalam kelayakan media pada respon siswa dengan kriteria interprestasi skor sangat layak.

\section{SIMPULAN DAN SARAN}

Berdasarkan hasil penelitian dan pembahasan serta penjelasan pada rumusan masalah dibab sebelumnya, maka dapat disimpulkan penelitian sebagai berikut, Kualitas produk komik sebagai 
media pembelajaran untuk kemampuan berpikir kritis berdasarkan hasil validasi oleh dosen ahli materi dan praktisi. Hasil akhir penilaian kelayakan media komik pada setiap komponen yaitu komponen kelayakan isi, materi dan media dikategorikan dengan 'Sangat Baik' oleh ahli dan praktisi, sehingga sangat layak untuk diuji cobakan. Kemudian untuk mengetahui peningkatan hasil belajar siswa yaitu dengan menghitung selisih antar skor pretes dan skor posttets dengan menggunakan rumus $\mathrm{n}$ gain skor. rata-rata skor pretess diperoleh 66 dan posttest diperoleh 80,2 dengan kriteria peningkatan memperoleh gain skor 0,41 dalam kategori 'Sedang'.

Berdasarkan kesimpulan diatas, peneliti memberikan beberapa saran dari penelitian pengembangan ini sebagai berikut, Media pembelajaran berupa komik berbasis digital diharapkan bisa membantu pendidik sebagai bahan ajar dalam menyampaikan materi khususnya pada materi metamorfosis disaat berlangsung nya pandemi covid-19, dan juga media komik ini dapat dipergunakan sebagai salah satu contoh dari variasi pembelajaran.

\section{DAFTAR RUJUKAN}

Amir, H. (2019). Metode Penelitian \& Pengembangan. Malang: CV. Literasi Nusantara.

Amir, M.F (2015). "Proses Berpikir Kritis Siswa Sekolah Dasar Dalam Memecahkan Masalah Berbentuk Soal Cerita Matematika Berdasarkan Gaya Belajar". Jurnal pada Math Educator Nusantara, (01), 163.

Arsyad, A. (2017). Media Pembelajaran. Jakarta: PT Raja Grafindo Persada.

Burhan, N. (2018). Sastra Anak: Pengantar Pemahaman Dunia Anak. Yogyakarta: Gadjah Mada University Press.

Desstya, Anatri. (2014). "Kedudukan dan Aplikasi Pendidikan Sains di Sekolah Dasar". Jurnal pada Profesi Pendidikan Dasar FKIP Universitas Muhammadiyah Surakarta, (Vol.1), 194-195.
Dewi, dkk. (2013) "Pengaruh Model Pembelajaran Kooperatif Tipe Numbered Head Together ( NHT) Berbantuan Kit IPA Terhadap Kreativitas Dan Hasil Belajar Siswa Pada Mata Pelajaran IPA Kelas IV SD”. Jurnal Pada e-Journal Program Pascasarjana Universitas Pendidikan Ganesha, (3), 3.

Eko, P.Y. (2017). Evaluasi Program Pembelajaran. Yogyakarta: Pustaka Pelajar

Fatimah \& Widiyatmoko. (2014). "Pengembangan Science Comic Berbasis Problem Based Learning Sebagai Media Pembelajaran Pada Tema Bunyi Dan Pendengaran Untuk Siswa SMP”. Jurnal pada Jurnal Pendidikan IPA Indonesia". (2), 152.

Hakim, A.F. (2017). Pengembangan Komik Digital Sebagai Media Pembelajaran Alat-Alat Pembayaran Internasional Pada Materi Perekonomian Terbuka. Skripsi.UNY

Hildayatni, D. (2015). "Pengaruh Modul Pembelajaran IPA Terintegrasi Nilai Agama Terhadap Peningkatan Karakter Rasa Ingin Tahu Siswa". Jurnal pada Jurnal Madrasah Ibtidaiyah Universitas Ibn Khaldun Bogor, (5), 3.

Kuswana, W.S. (2013). Taksonomi Berpikir. Bandung: PT Remaja Rosdakarya.

Laksana S.D, (2015). "Komik Pendidikan Sebagai Media Inofatif Mi/Sd". Jurnal pada Ta'allum, (Vol.3), 157.

Lestari, I. (2016) "Pengembangan Bahan Ajar IPA Komik pada Pokok Bahasa Gerak di SMP". Jurnal pada Seminar Nasional Pendidikan FKIP Pendidikan Fisika Universitas Jember. (1). 566.

Lismaya, L. (2019). Berpikir Kritis \& PBL (Problem Based Learning). Surabaya: Media Sahabat Cendikia.

Maharsi, I. (2014). Komik (dari wayang beber sampai komik digital). Yogyakarta: Badan Penerbit Isi Yogyakarta. 
Mawaddah. M. (2016). Pengembangan Komik Digital Sebagai Media Pembelajaran Etiket Makan Di Dalam Keluarga. UNY

Muri, A.Y. (2017). Metode Penelitian. Jakarta: PT. Interpratama Mandiri.

Nalinda, H. (2018). Pengembangan multimedia interaktif berbasis Problem Based Learing pada muatan pelajaran IPA kelas IV SDN Kalisegoro Semarang. Skripsi UNNES

Nizwardi, J. \& Ambiyar. (2016). Media dan Sumber Pembelajaran. Jakarta: Kencana

Pebriansyah. (2015). "Pengembangan Pembuatan Media Komik Berbasis Komputer Sebagai Alat Bantu Pembelajaran Sistem Bahan Bakar". Jurnal pada Jurnal Pendidikan Teknik Mesin FKIP Universitas Sriwijaya, (Vol.2), 67.

Pengelola web kemdikbud. (2017). Pendidikan Karakter Dorong Tumbuhnya Kompetensi Siswa Abad 21.[Online] Tersedia: https://www.kemdikbud.go.id. [14 Juni 2017].

Riduwan. (2019). Skala Pengukuran VariabelVariabel Penelitian. Bandung: Alfabeta.

Sari, I.P. dkk. (2019). "Pengintegrasian Penilaian Formatif dalam Pembelajaran IPA Berbasis Saintifik Terhadap Pemahaman Konsep Peserta Didik". Jurnal pada Pendidikan IPA Veteran Fakultas Matematika dan IPA Universitas Negeri Malang, (3), 53.

Sihotang, K. (2019). Berpikir Kritis Kecakapan Hidup Di Era Digital. Yogyakarta: PT Kanisius.

Sugiyono. (2015). Metode Penelitian Pendidikan (Pendekatan kuantitatif, Kualitatif dan $R \& D)$. Bandung: Alfabeta.
Suhartini \& Martyani. (2017). "Meningkatkan Kemampuan Berpikir Kritis pada Pembelajaran Geometri Berbasis Etnomatematika". Jurnal pada Jurnal Gantang Program Studi Pendidikan Matematika Universitas Alam Ata Yogyakarta, (2), 107.

Sundayana, H. (2017). Statistika Penelitian Pendidikan. Bandung: Alfabeta.

Suryabrata, S. (2015). Psikologi Pendidikan. Jakarta: PT Rajagrafindo Persada.

Susanto, A. (2013). Teori Belajar dan Pembelajaran di Sekolah Dasar. Jakarta: Kencana.

Suyono, \& Hariyanto. (2016). Belajar dan Pembelajaran. Bandung: PT.Remaja Rosdakarya.

Usep, K. (2016). Pengembangan Media Pembelajaran Anak Usia Dini. Malang: Gunung Samudera.

Wedyawati \& Lisa. (2019). Pembelajaran IPA di Sekolah Dasar. Yogyakarta: CV Budi Utama.

Yusuf, M. (2017). Metode Penelitian (Kuantitatif, Kualitatif, Penelitian Gabungan). Jakarta: Kencana

Zuhrowati, M. dkk (2018). "Pengembangan Komik Sebagai Media Pembelajaran IPA pada Materi Pemanasan Global”. Jurnal pada Pendidikan Fisika Universitas Muhammadiyah Metro, (Vol. 6), 145. 